\title{
Keräkaali- ja porkkanalajikkeiden aistinvarainen arviointi
}

\author{
Anu Räty ${ }^{1)}$, Jussi Veijola ${ }^{2)}$, Kaisa Soppela ${ }^{2)}$ \\ ${ }^{1)}$ MTT Sotkamo, Kipinäntie 16, 88600 Sotkamo, etunimi.sukunimi@mtt.fi \\ ${ }^{2)}$ MTT Rovaniemi, Eteläranta 55, 96300 Rovaniemi, etunimi.sukunimi@mtt.fi
}

\section{Tiivistelmä}

Eri kaali- ja porkkanalajikkeiden aistittavassa laadussa ja käyttöominaisuuksissa voi olla suuriakin eroja. Toiset lajikkeet ovat parhaimmillaan tuorekäytössä, kun toiset paranevat kypsennettäessä. Lapin keittiömestarit r.y. arvioi MTT Rovaniemen Apukan viljelykokeiden porkkana- ja keräkaalilajikkeiden soveltuvuutta ammattikeittiökäyttöön aistinvaraisten ominaisuuksien perusteella. Arviointi suoritettiin Saamelaisalueen Koulutuskeskuksessa Ivalossa. Viljelykokeet olivat osa MTT Sotkamon koordinoimaa Vihannesviljelystä vahva elinkeino Pohjois-Suomeen-hanketta, jota rahoittaa EU:n Maaseuturahasto Kainuun, Pohjois-Pohjanmaan ja Lapin ELY-keskusten kautta. Yhteistyössä oli mukana Lappi luo II - työohjelma, rahoittajana EU:n maaseuturahasto Lapin ELY - keskuksen kautta.

Arvioitavana oli kahdeksan porkkana- ja valkokaalilajiketta sekä yksi punakaalilajike. Jokaisesta lajikkeesta valmistettiin vakioreseptillä arvioitavat tuotteet. Porkkanasta arvioitavana olivat raaka ja kypsennetty kuutio sekä porkkanatimbaali. Valko- ja punakaalista arvioitiin raaka ja höyrytetty raaste. Valkokaalista valmistettiin kaalikääryleet ja punakaalista haudutettu punakaalilisäke.

Jokaisesta lajikkeesta sekä tuotteesta arvioitiin maku, tuoksu, rakenne ja väri sekä lajikkeen soveltuvuus kyseisen ruokalajin valmistukseen. Lajikkeista arvioitiin myös soveltuvuus Horecakäyttöön. Horeca tarkoittaa elintarvikekaupan suurasiakasryhmää, joka sisältää hotelleja, ravintoloita ja muita ruokapalveluyrityksiä. Hävikkien määrittämiseksi jokaisesta lajikkeesta mitattiin lähtöpaino, käsittelyn jälkeinen raakapaino sekä kaalilla myös paino kypsennyksen jälkeen.

Raadin mielestä valkokaalin talvilajike Paradox ja syyslajike Brady maistuivat parhaimmilta. Niiden rakenne oli hyvä sekä raakana että kypsänä. Paradox ja Brady olivat parhaita valmiina tuotteena sekä soveltuivat parhaiten myös Horeca-käyttöön. Lennox-lajikkeen raakana hieman kova, tikkuinen rakenne pehmeni kypsennettäessä. Samalla myös maku muuttui miedommaksi. Punakaalista Rodeo-lajikkeen väri ja rakenne raakana arvioitiin hyväksi. Maku arvioitiin mitättömäksi, ei kaalimaiseksi. Raakana maku oli parempi kuin kypsänä. Punakaalilisäke ei maistunut ja lajiketta ei pidetty Horeca-käyttöön soveltuvana.

Porkkanan varastolajiketta Maestro pidettiin maultaan ja tuoksultaan parhaana. Lisäksi sen rakenteesta pidettiin sekä raakana että kypsennettynä. Muita maultaan hyviä olivat Namdal ja Silvano. Lajikkeet Extremo, Maestro ja Silvano säilyttivät värinsä hyvin kypsennyksen aikana. Silvanolajikkeella myös maku tuntui voimistuvan kypsennettäessä. Porkkanatimbaali onnistui raadin mielestä parhaiten lajikkeista Extremo ja Maestro. Horeca-käyttöön soveltuivat lajikkeet Extremo, Maestro ja Silvano.

\section{Asiasanat}

Aistinvarainen arviointi, porkkana, valkokaali, punakaali, lajikkeet 


\section{Johdanto}

Ihmisten ruokavalintoihin vaikuttavat ruoan aistittavat ominaisuudet, joita ovat maku, tuoksu, ulkonäkö ja rakenne. Ruuan makuun ja rakenteeseen taas vaikuttavat ruuan valmistuksessa käytettävät raakaaineet. Vihannesten ja juuresten eri lajikkeiden aistittavassa laadussa ja käyttöominaisuuksissa voi olla suuriakin eroja. Toiset lajikkeet ovat parhaimmillaan tuorekäytössä ja menettävät makua ja rakenne kärsii kypsennettäessä. Kun taas toisten lajikkeiden maku ja muut ominaisuudet vain paranevat kypsennyksen aikana.

Ruuan aistittavaa laatua voidaan selvittää kahdella eri menetelmällä. Aistinvaraisessa tutkimuksessa koulutettu raati arvioi elintarvikkeita ja ruuan hyväksyttävyys tutkimuksessa tavalliset kuluttajat arvioivat elintarvikkeita. Tässä tutkimuksessa haluttiin selvittää eri porkkana- ja kaalilajikkeiden soveltuvuutta erilaisiin käyttötarkoituksiin. Menetelmänä käytettiin aistinvaraista arviointia, jonka suorittivat ravintolakeittiöiden ammattilaiskeittiömestarit.

Kokeet olivat osa MTT Sotkamon koordinoimaa Vihannesviljelystä vahva elinkeino PohjoisSuomeen - hanketta, jota EU:n maaseuturahasto rahoittaa Kainuun, Pohjois-Pohjanmaan ja Lapin ELY-keskusten kautta.

\section{Aineisto ja menetelmät}

Aistinvaraisessa arvioinnissa oli mukana kuusi porkkanan varastolajiketta (Carboli, Exelso, Morelia, Merida, Maestro ja Namdal) sekä kaksi teollisuuslajiketta (Silvano ja Extremo). Valkokaalista arvioitiin neljä syyslajiketta (Amazon, Tekila, Brady, Concul)) ja neljä talvikaalilajiketta (Attraction, Lennox, Sting, Paradox). Lisäksi mukana oli yksi punakaalilajike, Rodeo.

Jokaisesta lajikkeesta valmistettiin vakioreseptillä arvioitavat tuotteet. Porkkanalla arvioitavat tuotteet olivat raaka ja kypsennetty kuutio sekä porkkanatimbaali. Kaalilla arvioitavana olivat raaka ja höyrytetty raaste sekä kaalikääryleet jauheliha-ohrasuurimotäytteellä. Punakaalista valmistettiin omenaa, punasipulia ja purjoa sisältävä haudutettu punakaali.

Aistinvaraisessa arvioinnissa jokaisesta lajikkeesta ja tuotteesta arvioitiin maku, tuoksu sekä rakenne ja väri raakana että kypsänä. Lisäksi arvioitiin lajikkeen soveltuvuus kyseisen ruokalajin valmistukseen sekä Horeca-käyttöön. Horeca tarkoittaa elintarvikekaupan suurasiakasryhmää, joka sisältää hotelleja, ravintoloita ja muita ruokapalveluyrityksiä. Hävikkien määrittämiseksi jokaisesta lajikkeesta mitattiin alkupaino, käsittelyn jälkeinen raakapaino sekä kaalilla myös paino kypsennyksen jälkeen.

Aistinvaraisen arvioinnin toteuttivat Lapin keittiömestarit ry:n neljä ravintolakeittiöiden ammattilaiskeittiömestaria. Arviointi suoritettiin Saamelaisalueen Koulutuskeskuksen opetuskeittiön tiloissa Ivalossa. Arvioitavat tuotteet ja ruokalajit valmistettiin vakio reseptillä. Valmistuksesta huolehtivat koulutuskeskuksen opettaja ja hänen oppilaansa.

\section{Tulokset ja tulosten tarkastelu}

\section{Porkkanat}

Porkkanoista varastolajike Maestro sekä teollisuuslajikkeet Extremo ja Silvano saivat arvioinnissa parhaimmat kokonaispisteet (taulukko1). Varastolajike Namdal tuli neljänneksi.

Maultaan parhaimmiksi lajikkeiksi arvioitiin Maestro, Namdal ja Silvano. Näistä Maestro-lajike oli raadin mielestä myös tuoksultaan sekä rakenteeltaan raakana ja kypsänä paras. Sen rakenne säilyi hyvin kypsennyksen aikana. Lajikkeista Extremo, Maestro ja Silvano valmistetut kypsät kuutiot säilyttivät hyvin värinsä. Silvano-lajikkeella myös maku voimistui kypsennettäessä. Lajiketta Namdal luonnehdittiin makeaksi ja sen ansioista hyväksi raasteporkkanaksi.

Paras porkkanatimbaali valmistui lajikkeista Extremo ja Maestro. Lajikkeista parhaiten Horecakäyttöön soveltuivat Extremo, Maestro ja Silvano.

Osalla porkkanalajikkeista raakahävikit olivat suuria, johtuen lähtöpainossa mukana olleista pienistä ja käyristä porkkanoista. 
Taulukko 1: Eri porkkanalajikkeiden aistinvaraisessa arvioinnissa saamat kokonaispisteet (keskiarvoja). Arvioinnissa käytettiin asteikkoa 1-5, jossa 1 on huonoin ja 5 paras. Hävikit on ilmoitettu prosentteina lähtöpainosta.

\begin{tabular}{|l|c|c|c|c|c|c|c|c|}
\hline & Carboli & Exelso & Morelia & Merida & Maestro & Namdal & Silvano & Extremo \\
\hline Maku & 3,0 & 3,3 & 1,5 & 2,0 & 4,0 & 4,0 & 4,0 & 3,8 \\
\hline Tuoksu & 3,3 & 2,8 & 1,5 & 2,0 & 3,8 & 3,5 & 3,5 & 3,8 \\
\hline $\begin{array}{l}\text { Rakenne raa- } \\
\text { kana }\end{array}$ & 2,8 & 3,3 & 1,5 & 3,0 & 4,3 & 3,3 & 3,8 & 4,0 \\
\hline $\begin{array}{l}\text { Rakenne kyp- } \\
\text { sänä }\end{array}$ & 2,3 & 3,3 & 2,3 & 2,8 & 4,3 & 3,5 & 4,0 & 3,8 \\
\hline Väri raakana & 3,0 & 2,5 & 2,3 & 2,3 & 3,3 & 2,8 & 3,8 & 3,0 \\
\hline Väri kypsänä & 2,3 & 3,3 & 2,3 & 2,5 & 3,5 & 3,0 & 4,0 & 3,3 \\
\hline Valmis tuote & 2,8 & 2,5 & 3,0 & 2,8 & 3,5 & 2,3 & 2,5 & 3,5 \\
\hline $\begin{array}{l}\text { Soveltuvuus } \\
\text { HORECA- } \\
\text { käyttöön }\end{array}$ & 2,5 & 2,8 & 2,0 & 2,5 & 3,8 & 3,0 & 3,8 & 3,8 \\
\hline $\begin{array}{l}\text { Pisteiden kes- } \\
\text { kiarvo }\end{array}$ & 2,7 & 2,9 & 2,0 & 2,5 & 3,8 & 3,2 & 3,7 & 3,6 \\
\hline $\begin{array}{l}\text { Raakahävikki } \\
\text { \% }\end{array}$ & 36,9 & 27,4 & 20,1 & 38,0 & 20,1 & 17,9 & 21,0 & 21,4 \\
\hline
\end{tabular}

\section{Keräkaalit}

Keräkaalilajikkeista parhaiten pärjäsivät talvilajike Paradox ja syyslajike Brady (taulukko 2). Ne saivat korkeimmat pisteet mausta raakana sekä rakenteesta raakana ja kypsänä. Paradox-lajike kesti hyvin kypsennyksen ja maku parani ja väri voimistui kypsennettäessä. Sen sijaan Brady-lajikkeen väri vaaleni kypsennyksen aikana muuttuen hailakaksi, ja osan mielestä samalla myös sen maku häipyi.

Paradox ja Brady lajikkeista valmistui parhaat kaalikääryleet ja ne soveltuivat raadin mielestä parhaiten myös Horeca-käyttöön.

Punakaalilajikkeen Rodeo rakenne ja väri raakana arvioitiin hyväksi, mutta kaalin maku arvioitiin mitättömäksi, ei ollenkaan kaalimaiseksi.

Taulukko 2: Kaalilajikkeiden aistinvaraisessa arvioinnissa saamat kokonaispisteet (keskiarvoja). Arvioinnissa käytettiin asteikkoa 1-5, jossa 1 on huonoin ja 5 paras. Hävikit on ilmoitettu prosentteina lähtöpainosta.

\begin{tabular}{|l|c|c|c|c|c|c|c|c|c|}
\hline & $\begin{array}{l}\text { Ama- } \\
\text { zon }\end{array}$ & Tekila & Brady & Consul & $\begin{array}{l}\text { Attrac- } \\
\text { tion }\end{array}$ & $\begin{array}{l}\text { Len- } \\
\text { nox }\end{array}$ & $\begin{array}{l}\text { Sting } \\
\text { F1 }\end{array}$ & $\begin{array}{l}\text { Para- } \\
\text { dox }\end{array}$ & Rodeo \\
\hline Maku & 3,0 & 2,0 & 3,8 & 2,8 & 2,5 & 2,3 & 3,0 & 3,5 & 2,8 \\
\hline Tuoksu & 2,3 & 1,5 & 2,3 & 1,8 & 2,0 & 1,5 & 2,5 & 1,8 & 2,3 \\
\hline $\begin{array}{l}\text { Rakenne } \\
\text { raakana }\end{array}$ & 3,8 & 2,3 & 4,0 & 3,5 & 3,8 & 3,0 & 3,5 & 4,0 & 4,3 \\
\hline $\begin{array}{l}\text { Rakenne } \\
\text { kypsänä }\end{array}$ & 3,8 & 2,5 & 3,8 & 3,5 & 3,8 & 3,5 & 3,0 & 4,3 & 2,8 \\
\hline Väri raakana & 2,8 & 2,0 & 3,0 & 3,3 & 2,3 & 2,3 & 3,8 & 2,5 & 3,8 \\
\hline Väri kypsänä & 3,8 & 2,3 & 2,3 & 3,0 & 2,8 & 3,3 & 3,3 & 3,8 & 2,3 \\
\hline Valmis tuote & 3,5 & 2,3 & 4,8 & 3,3 & 4,0 & 3,8 & 3,8 & 4,8 & 2,3 \\
\hline $\begin{array}{l}\text { Soveltuvuus } \\
\text { HORECA- } \\
\text { käyttöön }\end{array}$ & 3,0 & 2,0 & 4,0 & 2,8 & 3,5 & 3,0 & 3,5 & 4,8 & 1,7 \\
\hline $\begin{array}{l}\text { Pisteiden } \\
\text { keskiarvo }\end{array}$ & 3,2 & 2,1 & 3,5 & 3,0 & 3,1 & 2,8 & 3,3 & 3,7 & 2,7 \\
\hline $\begin{array}{l}\text { Raakahävik- } \\
\text { ki \% }\end{array}$ & 12,2 & 11,9 & 9,2 & 8,8 & 16,7 & 19,5 & 24,3 & 10,0 & 7,8 \\
\hline $\begin{array}{l}\text { Kypsennys- } \\
\text { hävikki \% }\end{array}$ & 6,4 & 7,4 & 4,0 & 6,8 & 5,9 & 7,7 & 12,5 & 7,7 & 4,7 \\
\hline
\end{tabular}




\section{Johtopäätökset}

Eri porkkana- ja kaalilajikkeiden välillä aistittavassa laadussa ja käyttöominaisuuksissa on suuria eroja. Aistinvaraisessa arvioinnissa porkkana- ja kaalilajikkeista nousi esille muutamia ns. yleislajikkeita, jotka sopivat hyvin sekä raakana käytettäviksi että kypsennettäviksi ja ruuanvalmistukseen (Horecakäyttöön). Esille tuli myös lajikkeita, jotka ovat parhaimmillaan tuorekäytössä eivätkä soveltuneet kovin hyvin kypsennykseen ja ruuanvalmistukseen. Lisäksi tuli ilmi lajikkeita, joiden ominaisuudet vain paranivat ja voimistuvat kypsennettäessä. Jos viljelijällä on tiedossa porkkanoiden ja kaalin lopullinen käyttötarkoitus ja eri lajikkeiden aistittavista ominaisuuksista tiedetään, viljelyyn otettavan lajikkeen valinta kannattaa.

Kasvukaudella 2012 säät olivat koleat ja kasvukausi jäi lyhyeksi. Esimerkiksi kaalien talvilajikkeet eivät ehtineet keriä Pohjois-Suomessa, kuten ne kasvukaudella 2011 ehtivät. Myös porkkanasadossa esiintyi kaudella 2012 paljon pieniä porkkanoita. Tästä johtuen porkkanoiden raakahävikit olivat suuria. Raakahävikkien suuruus on sadon laadusta riippuvainen. Sadonlaatu riippuu taas paljon kasvukauden olosuhteista (sääolot, tuholaisten esiintyminen). 